\title{
Analysis of E-Readiness in Distance Learning at Korwilcam Dindik Public Elementary Schools Kedungbanteng, Banyumas Regency
}

\author{
Sulastri $^{1}$, Yahya Sudarya ${ }^{2}$ \\ $\left\{\underline{\text { lastrie72@gmail.com }}\right.$, yahyasudarya@yahoo.com $\left.{ }^{2}\right\}$ \\ ${ }^{1,2}$ Universitas Muhammadiyah Purwokerto
}

\begin{abstract}
The research purposes to analyze the readiness of implementing e-learning and reveal what factors are still weak / need improvement and what factors are considered successful / strong in supporting the application of e-learning in Distance Learning in public elementary schools Korwilcam Dindik Kedungbanteng Regency. Banyumas. Survey method was used. The model used is ELR Aydin \& Tasci, which consists of four factors: 1) humans, 2) self-development, 3) technology, and 4) innovation. The results showed that the readiness of implementing e-learning at Distance Learning in public elementary schools of Korwilcam Dindik Kedungbanteng, Banyumas Regency was in the ready category, but needed a little improvement. Meanwhile, for each ELR factor that is still weak / unprepared, it needs a little improvement. Other factors that are considered successful / ready, require a little improvement, such as self-improvement, technology, and innovation.
\end{abstract}

Keywords: e- readiness, distance learning, elementary school

\section{Introduction}

There is a paradigm shift in education, which was originally in the classroom at a certain time, now it becomes learning that can be done anytime and anywhere, not limited to space and time [4][8]. This situation is in line with the COVID-19 pandemic, all levels of education are carried out online / Distance Learning without face to face [1-3]. Online learning aims to prevent the very high transmission of the COVID-19 outbreak due to physical interaction during learning activities.

Distance learning activities provide different challenges for teachers, students and schools. Especially for teachers, they must prepare various ways so that the subject matter can be conveyed and received properly. Students need greater effort in terms of material, energy and psychological readiness in learning activities. Schools act as facilitators in providing information technology for teachers and students during learning activities [2][4].

Another factor of information technology that is no less important in disctance learning activities is the internet application. One application that is often used to deliver learning, such as Google Classroom, is an alternative in schools in delivering material [1]. This situation has resulted in several new problems in terms of the availability of supporting device and human resources who do not master information technology coupled with demands to master e-learning which brings new colors to changes in the education system during distance learning [1][4]. Especially for the Banyumas Regency area at the primary education level, many have started to implement e-learning when distance learning(PJJ)uses the Google Classroom application. This indicates that the openness of using e-learning has reached a basic level. Optimizing the 
application of e-learning requires the readiness of both infrastructure and school organizational culture [15]. Readiness to use e-learning is known as e-learning readiness. Measurement of elearning readiness is carried out so that schools can find out their level of readiness. By knowing the level of readiness, schools can determine the policies or strategies to be determined [5][6].

\section{Method}

This research method is a descriptive study using a questionnaire with a research model using ELR Aydin \& Tasci [7], which has been adjusted so that it can be used in research, including factors: 1) humans, 2)self-development, 3) technology, and 4) innovation. The research subjects were aimed at 6 school principals and 6 teachers in public elementary schools Korwilcam Dindik Kedungbanteng, Banyumas Regency. The data analysis technique used the check list method on the appropriate choice on the questionnaire sheet. The scores used, namely 5,4,3,2 and 1 for each assessment of the answer to the respondent, the total score will be obtained, then calculated using the following formula:

$$
\bar{x}=\frac{\sum x}{n}
$$

Explanation

$\mathrm{x}=$ final score

$\Sigma=$ total score

$\mathrm{n}=$ number of respondence

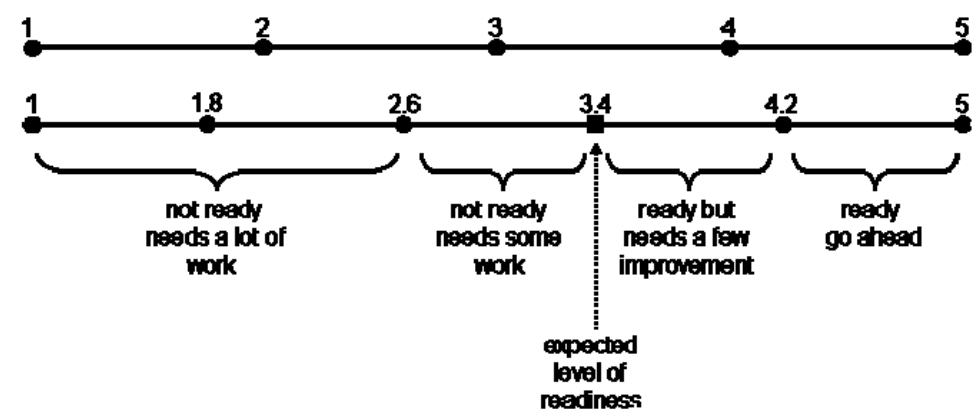

Figure 1. Assessment model of the e-LRS (Aydin \& Tasdi) 


\section{Results and Discussion}

The results of the score for filling out the e-learning readiness questionnaire by the research subjects can be made in Table 1 below:

Table 1. Final Score Results of E-Readiness in Puclic Elementary School Korwilcam Dindik Kedungbanteng, Banyumas Regency

\begin{tabular}{|c|c|c|c|}
\hline ELR Factors & Total Score & ELR Score $(x)$ & Category \\
\hline Human Factors & 313 & $3,3 \quad$ Not $\mathrm{r}$ & ds a little improvement \\
\hline Self Development Factors & 408 & Read & ds a little improvement \\
\hline Technology Factors & 519 & Read & eds a little improvement \\
\hline Innovation Factors & 225 & Read & eds a little improvement \\
\hline Total ELR & 1465 & Read & eds a little improvement \\
\hline
\end{tabular}

Based on Table 1, the final score of E-readiness/ELR $x=3.6>3.41$ indicates that the Puclic Elementary School in Korwilcam Dindik Kedungbanteng, Banyumas Regency is ready to implement e-learning, but requires a little improvement. The increase was made to the ELR factor which had a low score. The weak ELR factor is the human factor, because it has a value of $x<3.41$. The increase in the ELR factor is not only done to overcome the ELR score which has a value of $x<3.41$. The increase was also made to increase the ELR score that each ELR factor had. An increase in the ELR factor can also indicate parts that need to be paid more attention to the ELR factor, in more detail as follows:

\section{1) Human Factors}

The human factor at the Korwilcam Dindik public elementary school, Kedungbanteng, Banyumas Regency is categorized as not ready, it needs a little improvement. This unpreparedness can be caused by factors of teachers and school principals as implementers of the e-learning program not all implement:

a) A comprehensive and continuous e-learning training program. E-learning training aims to provide teachers with the expertise and experience of using e-learning. Teachers who already have expertise and experience are expected to be able to take advantage of e-learning in the learning process. Training has a positive impact on the improvement of the implementation of e-learning. Training that can be done to increase the effectiveness of using e-learning, such as the use of LMS and Blanded Learning models [8][6][11][[13]. In addition, the existence of expert shering and e-learning simulations also affects the improvement of human factors [14].

b) Regularity in managing e-learning implementation policies. If the school principal already knows very well about the policy of implementing e-learning through various trainings, either organized by the relevant office or the private sector, then the e-learning readiness level will meet the standards ready and can be continued. The lack of knowledge of the principal as a policy manager will have an impact on teachers, students and parents as companions when the implementation of e-learning as a means of distance learning is less than the specified standard, with students not having communication in collaboration with teachers or between students in completing the given task and parents do not accompany and supervise e-learning activities, so a decrease in the human factor e-learning readiness score can occur. This situation also occurs 
in previous studies that in human factors with a lack of knowledge in making policies, a decrease in e-learning readiness scores on human factors can occur [15][16]. This human factor is the key to E-readiness. If the policy has been carried out correctly and implemented regularly, it will be correlated with other factors in the readiness to implement e-learning [10].

\section{2) Self Development Factors}

Development factors at the Korwilcam Dindik public elementary school, Kedungbanteng, Banyumas Regency are categorized as ready, but need a little improvement. Some improvements that can be made to maximize self-development factors:

a) Increase in teacher e-learning competence by giving structured assignments, so that students can learn to access e-learning properly. Giving assignments in a structured manner besides being able to increase the score of readiness results will also have an impact on the ease with which students learn to use e-learning can be done well [4][12].

b) Increased self-confidence in implementing e-learning learning will correlate with the increase in student learning outcomes, so the learning process with e-learning will run optimally. If the teacher lacks self-confidence it will also cause confusion to students, especially parents, therefore to get a maximum e-learning readiness score the teacher must be confident in carrying out e-learning-based activities [6][9][15][20].

c)Increase in the provision of budget funds for the application of e-learning. Before implementing the e-learning program, it needs to be discussed properly in school board meetings. Budget planning can show that the sources of funds from the schools themselves are sufficient or insufficient. A careful budget planning will provide good and maximum implementation results. Although in fact there is already a central budget for the

implementation of online learning, it is limited to a predetermined application. In practice, elearning uses a variety of applications, both free and paid access [2][5][4][7].

\section{3)Technology Factors}

Technological factors at the Korwilcam Dindik public elementary school, Kedungbanteng, Banyumas Regency are categorized as ready, but need a little improvement. Several improvements can be made to maximize the technological factor, namely the addition of infrastructure in anticipation of constraints on the stability of the internet, due to natural conditions such as rain and mountainous contours in the Puclic Elementary School in Korwilcam Dindik Kedungbanteng, Banyumas Regency, making the signal sometimes fluctuate so that it disturbs the implementation e-learning. This technological factor is also a companion to the success of the implementation of e-learning, this shows that the faster access to technology in the implementation of e-learning, the readiness score will increase [6]. On the other hand, access to technology is very difficult, it reflects that E-readiness is not running optimally, and has an impact on disruption/stagnation in the form of information both in terms of learning materials and rules in learning activities [16][17]. 


\section{4) Innovation Factor}

The innovation factor at the Korwilcam Dindik public elementary school,Kedungbanteng, Banyumas Regency is categorized as ready, but needs a little improvement. Several improvements can be made to maximize the innovation factor, its by focusing on the renewal and creativity side of the implementation of the e-learning program. Even though in practice several in Korwilcam Dindik Kedungbanteng, Banyumas Regency have made innovations in the use of e-learning applications that are not monotonous using only one application. These applications vary, such as: 1) google classrom, 2) zoom, 3) google swift, 4) microsoft 360, 4) schoology etc. These various applications are one of the advantages in implementing e-learning, but it does not rule out that the provision of technology infrastructure (applications) and training for school human resources does not guarantee the success of e-learning, organizational culture and leadership factors, both teachers and school principals have an influence. of the success of e-learning [4][10][13] [21-23].

\section{Conclusion}

Based on the results and discussion in the description above, the readiness for the application of e-learning during Distance Learning at the Korwilcam Dindik public elementary school, Kedungbanteng, Banyumas Regency is in the ready category, but requires a slight increase with a final ELR score of 3.6. For each ELR factor that is still weak / unprepared, requiring a little improvement is a human with an ELR score of 3.3. Other factors that are considered successful / ready require a little improvement, such as self-improvement with an ELR score of 3.8, technology for an ELR score of 3.6, and innovation in a score of 3.8.

\section{References}

[1] Dewi, W.A.F :Dampak COVID-19 Terhadap Implementasi Pembelajaran daring di Sekolah Dasar. Jurnal Ilmu Pendidikan. 2 (1), 55-61, (2020).

[2] Herliandry, L.D., Nurhasanah., Suban, M.E., \& Kuswanto, H :Pembelajaran Pada Masa Pandemi COVID-19. Jurnal Teknologi Pendidikan. Vol. 22 (1), pp. 65-70, (2020).

[3] Purwanto, A., Pramono, R., Asbari, M., Santoso, P.b., Wijayanti, L.M., Hyun, C.c., \& Putri, R.S :Studi Eksploratif Dampak Pandemi COVID-19 Terhadap Proses Pembelajaran Online di Sekolah Dasar. Journal of Education, Psychology and Conseling. Vol. 2 (1), pp. $1-12,(2020)$.

[4] Obwoge, M.E \& Kwamboka, A.T :E-Readiness Status of Primary Schools Implementing Digital Devices in Kissi Caountry. I-Jes Journal, Vol. 8 (1),pp. 24-35, (2020) https://doi.org/10.3991/ijes.v8i1.12567.

[5] Fariani, R.I :Pengukuran Tingkat Kesiapan E-learning Studi Kasus pada Perguruan Tinggi ABC di Jakarta. Seminar Nasional Aplikasi Teknologi Informasi. pp. 1-7, (2013).

[6] Fajri, S.A :Pengukuran Tingkat Kesiapan Penerapan E-learning di SMK N 1 Banyumas (Skripsi). Yogyakarta: Universitas Negeri Yogyakarta (2018).

[7] Aydin, C.H \& Tasci D:Measuring Readiness for e-learning : Reflections from an Emerging country. Educational Technology \& Society, pp. 8(4) (2005). Uke, R :Aplikasi Model Mckinsey 7s Untuk Evaluasi Penerapan E-Learning di Sekolah Menengah Atas Bopkri Yogyakarta (Skripsi). Yogyakarta: Universitas Negeri Yogyakarta (2015).

[8] Lily \& Tatnall Arthur, B. S :A Framework for Investigating Blended Learning effectiveness, pp. 1-16, (2014) https://doi.org/10.1108/ET-04-2013-0049 
[9] Apeanti, W.O :Contributing Factors to Pre-Service Mathemathic Teachers e-readiness for ICT Integration. International Journal of Research in Education and Science. Vol. 2 (1), pp. 223-238 (2016).

[10] Durek, V \& Redep, N.B :Review on e-readiness assesment tools. Central European Conference on Information and Intelligent System, pp. 161-250, (2016).

[11] Hans, T., Chisaki, Y., \& Usagawa, T :Use of Facebook by Secondary School Students at Nuku'alofa as an Indicator of E-Readiness for E-learning in the Kingdom of Tonga. International Review of Research in Open and Distributed Learning. Vol. 17 (4), pp. 203 223, (2016).

[12] Fidaldo, P., \& Thormann, J :Reaching Students in Online Courses Using Alternative Formats. International Review of Research in Open and Distributed Learning.Vo. 18 (2), pp. 140-161, (2017).

[13] Mehran, P., \& Alizadeh, M. Designing and developing a Blended course : toward best practices for Japanese learners, pp.205-210, (2017).

[14] Dewi, K. C., Ciptayani, P. I., Surjono, H. D., \& Priyanto :Critical Success Factor for Implementing Vocational Blended Learning. Journal of Physics: Conference Series, Vol. 953(1), (2018)https://doi.org/10.1088/1742-6596/953/1/012086

[15] Yuwono T, Andriani A. Activeness Analysis Learns Elementary School Student On Online Learning During The Pandemic. Dinamika Jurnal Ilmiah Pendidikan Dasar. 2021 Sep 22;13(2):93-6.

[16] Hidayat, M. L :The Modification of LMS Quipperschool to Improve Senior High SchoolStudents ' Conce pt Mastery of Biology Subject, Topic : Human Reproduction Health. Journal of Educational Science and Technology (EST), Vol. 4(1), pp, 32-38, (2018).

[17] Anwar, O :Implementasi Pembelajaran Berbasis E-Learning Pada Masa Pandemi COVID19 di SD Muhammadiyah Plus Salatiga Tahun Pelajaran 2019/20 (Skripsi). Salatiga : IAIN Salatiga (2020).

[18] Vermeulen, L :Key Human Factors in the E-Readiness of Academic Employees at Higher Education Institutions. International Humanities Studies. Vol. 2 (2), pp. 1-40 (2015).

[19] Chandrawati, S. R :Pemanfaatan E-learning dalam pembelajaran. Jurnal Cakrawala Pendidikan, Vol. 8(2), pp. 172-181, (2010).

[20] Waryanto, $N$ \& Insani, $N$ :Tingkat Kesiapan (Readiness) Implementasi E-Learning di Sekolah Menengah Atas Kota Yogyakarta. Jurnal Pendidikan Matematika Dan Sains, pp. 117-124, (2013) http://journal.uny.ac.id/index.php/jpms/article/view/2478

[21] Wong Lily \& Tatnall Arthur, B. S :A Framework for Investigating Blended Learning effectiveness, pp. 1-16, (2014) https://doi.org/10.1108/ET-04-2013-0049

[22] Ilgaz, H., \& Gülbahar, Y :A Snapshot of Online Learners : e-Readiness , e- Satisfaction and Expectations, Vol. 16(2), pp. 171-187 (2015).

[23] Mukhasin M, Andriani A. The Influence of Used WhatsApp Group in Online Learning to Student Discipline at Elementary School. Dinamika Jurnal Ilmiah Pendidikan Dasar. 2021 Sep 22;13(2):76-8. 